\title{
大地震発生時における脆弱アクセシビリティ沿道区域の抽出方法 METHOD FOR EXTRACTING VULNERABLE ACCESSIBILITY ROADSIDE AREAS AFTER A LARGE EARTHQUAKE
}

\author{
田頭まき*1, 大佛 俊泰*2 \\ Maki TAGASHIRA and Toshihiro OSARAGI
}

\begin{abstract}
In order to reduce human casualty after a large earthquake, it is important to secure the smooth and rapid activities of emergency vehicles (e.g., ambulance services). However, there is a risk that road blockages will obstruct emergency activities and lead to the secondary damage. In this paper, we propose new accessibility indices to evaluate the accessibility of emergency transportation roads after a large earthquake. Moreover, performing the simulation that we have previously constructed, we extract the vulnerable roadside areas with poor accessibility to disaster base hospitals in Tokyo Metropolitan. Finally, we discuss the effective countermeasures to improve the accessibility indices.
\end{abstract}

Keywords : large earthquake, accessibility assessment, link isolation ratio, network isolation ratio, emergency transportation road, disaster base hospital 大地震，アクセシビリティ評価，リンク孤立率，ネットワーク孤立率，緊急輸送道路，災害拠点病院

\section{1. はじめに}

\section{(1) 研究の背景}

首都直下地震の発生が切迫する中, 大地震発生時の災害時活動 (広 域避難，救急消火活動，緊急物資の輸送，復旧復興活動など）を支 える重要なインフラストラクチャである緊急輸送道路 ${ }^{\text {1) }}$ の通行機 能（アクセシビリティ）の確保は，多くの地方自治体が取り組む喫 緊の課題である。例えば，東京都は，令和 7 年度までに，特定緊急 輸送道路沿道建築物の耐震化率を，現状（令和元年 12 月時点）の $85.9 \%{ }^{4)}$ から $100 \%$ まで改善することを目標としている ${ }^{1,2,3)}$ 。このよ うに，各地方自治体は，耐震化率や耐火率，道路の拡幅整備率など を整備目標に設定し，市街地整備に取り組んでいるが，これらの指 標から，大地震時のアクセシビリティを直接評価することは困難で ある。市街地整備を進める上で，それらをより明確に把握可能な指 標を整備目標として設定することが求められる。筆者らは，これま で, 特定沿道建築物の耐震化推進に関する検討を行う上で, アクセ シビリティに基づいた議論の有用性を示すことを目的に，東京都全 体で，マクロな視点から緊急輸送道路のアクセシビリティ評価およ び沿道建築物の耐震化推進によるアクセシビリティの改善効果につ いて, 定量的な検討を行ってきた ${ }^{5)}$ 。しかし，市街地整備に関する， より具体的な議論を行うためにも，道路ネットワークの性状や脆弱 な沿道建築物の空間分布などの局所的な特性に関する詳細な分析が 必要である。

本稿では，災害時にアクセシビリティが阻害される可能性が高い 緊急輸送道路の沿道区域を抽出することで，緊急輸送道路を用いた アクセシビリティ評価を，ミクロスケール（拠点施設単位・道路リ
ンク単位）に行うことを目的とする。なお，本稿では，前稿 ${ }^{5)}$ と同 様, 広域的な移動に伴う目的地までの到達可能性の視点からアクセ シビリティ指標を定義し,「緊急輸送道路の機能」という包括的な 概念を評価する。

従来の研究の多くは，特定の OD ペア間における緊急車両の移動 性に着目し, 到達可能性や移動の非効率性の視点からアクセシビ リティ評価を行なっている。その中でも，瀬戸ら ${ }^{6}$ ，原田ら ${ }^{7)}$ は， $\mathrm{OD} ヘ ゚ ア$ 間の到達可能性だけでなく, 移動経路の頑健性も評価可能 なアクセシビリティ評価指標を提案している点で優れている。具体 的には, 非重複経路本数が多い $\mathrm{OD}$ ペアほど頑強に連結され，アク セシビリティが高くなるという， $N$-edge-connected network ${ }^{8)}$ の概念 を用いて，非重複経路を考慮したアクセシビリティ評価を行なって いる。しかし，これらの研究では，特定の ODペア間の移動におけ る到達不能，また，大幅な迁回の原因となるアクセシビリティが脆 弱な沿道区域（緊急車両の通行機能が確保困難となる沿道区域）を 特定するまでには至っていない。

大地震発生時におけるアクセシビリティが脆弱な沿道区域の特定 方法については, 複数の研究が存在する。大澤ら ${ }^{9)}$ は, 建物倒壊, 橋梁の損傷, さらに, 斜面・切土の崩壊を物的被害として考慮して, 大地震時における重要拠点間の移動性を評価している。具体的に は，緊急車両の移動活動を記述可能なシミュレーションを用いて， 各道路区間が通行不能となる確率を算出し, アクセシビリティが脆 弱となる道路区間の評価を行なっている。なお，建物データに関す る詳細な属性情報が得られていないため，建物倒壊や道路閉塞の発 生確率を精緻に評価しているとは言い難い。この研究は, アクセシ
*1 東京工業大学環境 · 社会理工学院 助教 - 博士 (工学)

*2＼cjkstart東京工業大学環境・社会理工学院＼cjkstart教授·博士(工学)
Assist. Prof., School of Environment and Society, Tokyo Institute of Technology, Dr.Eng. Prof., School of Environment and Society, Tokyo Institute of Technology, Dr.Eng. 
ビリティが脆弱な沿道区域を抽出可能な点で優れているが，その評 価対象が重要拠点間の移動に関係する道路区間に限定されている点 で課題が残る。原田ら ${ }^{10)}$ は, 緊急車両による重要拠点への移動に 用いられる道路リンクをメッシュごとに抽出し，それぞれについて 連結信頼性を算出することで, 広域な分析対象地域におけるアクセ シビリティが脆弱な沿道区域の抽出を可能とした。しかし, 計算負 荷を抑えるため, 単純な想定の下での検討しか行なっておらず，連 結信頼性の算出においても, 厳密な計算を行なっていない。つまり, 複数の拠点への災害時活動など, 複雑な条件下におけるアクセシビ リティ評価には，この手法は不向きである。

\section{(2) 研究の目的}

本稿では, 大地震時の物的被害下において, 道路網から孤立する 道路に着目寸ることで, 活動拠点へのアクセシビリティが脆弱な沿 道区域を抽出する方法を提案する。具体的には, まず, 大地震時の 緊急活動において, 緊急車両の通行機能が阻害される可能性の高い 沿道区域を抽出するアクセシビリティ指標を提案する。次に, 前稿 5)で構築した，緊急輸送道路を用いた緊急車両の空間移動を記述す る緊急車両シミュレーションモデルを改良し, 東京都全域を分析対 象地域としてシミュレーションを実行することで, 災害拠点病院 ${ }^{12}$ への移動を想定したアクセシビリティ評価を行う。さらに, それら の沿道区域におけるアクセシビリティを改善させるための方策につ いて検討する。

大地震時には, 建物全壊だけでなく, 高架・橋脚の落下, 液状化, 道路のひび割れや電柱の倒壊など, 様々な物的被害が想定される。 また，交通渋滞の影響も無視することはできない。しかし，ここで は, 前稿 ${ }^{5)}$ と同様に, よりシンプルな想定の下で議論を行うため, 沿道建築物の全壊に起因する道路閉塞のみに着目する。

\section{2. アクセシビリティ評価指標の構築}

大地震時において緊急車両の通行機能が阻害される可能性の高い 沿道区域を抽出するためのアクセシビリティ指標を提案する。大地 震時には, より多くの活動拠点へ到達可能な沿道区域ほど, アクセ シビリティが高いと考えられる。そこで, 緊急車両の活動圈域内に 存在する全活動拠点 $(N$ 箇所) に占める到達可能な活動拠点 $(n$ 箇所) の割合 $p(=n / N)$ を用いてアクセシビリティの評価を行う。なお, 本 稿では, 交差点間を繋ぐ道路を道路リンク, 到達可能である活動拠 点の割合が $p$ 未満である道路リンクを孤立リンクと定義する。例え ば， 3 箇所の活動拠点を有する道路網上に複数の閉塞道路が発生し ている状況を想定する（Fig. 1(a)）。この時， $p=2 / 3$ における孤立リ ンクを求めると, Fig. 1(a) 中央の図の点線部分となる。

本稿では, リンク孤立率（以下，LI值；The value of Link Isolation ratio）とネットワーク孤立率（以下，NI 值；The value of Network Isolation ratio）という 2 つのアクセジ゙リティ指標を提案する（Fig. 1(b))。LI 值は「全シミュレーション試行 $(K$ 回 $)$ の内, 道路リン ク $i$ から到達可能である活動拠点の割合が $p$ 未満である回数の割 合」, NI 值は「孤立リンクの総延長が道路網の総延長に占める割合」 と定義する。LI 值は, 道路リンク単位で, NI 值は, 道路網単位で アクセシビリティを評価する指標である。これらの指標を用いるこ とで, 広域な分析対象地域において, 活動拠点へのアクセシビリティ が脆弱な沿道区域を抽出することが可能となる。

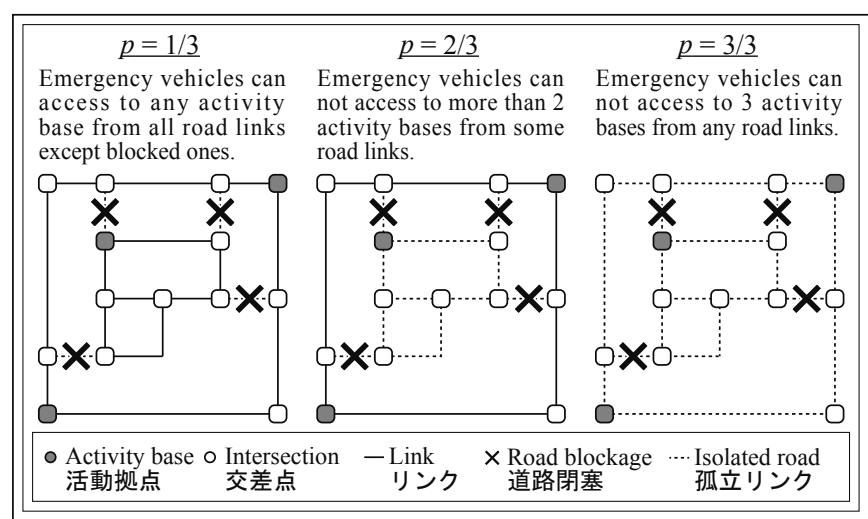

(a) Example of spatial distribution of road blockage and isolated road considering $p$, the ratio of accessible activity bases.

$$
\begin{aligned}
& \operatorname{LI}_{i}(p)=1-\Sigma_{k \in K} \delta_{i, k}\left(p_{A}\right) / \Sigma_{k \in K} 1 \\
& \mathrm{NI}_{A}(p)=1-\sum_{k}^{K} \Sigma_{i \in R} l_{i}\left(p_{A}\right) / \Sigma_{k}^{K} \Sigma_{i \in R} L_{i} \\
& p_{A}=n_{A} / N_{A}
\end{aligned}
$$

$K \quad:$ The number of simulation run

$\delta_{i, k}(p)$ : The arrival status at the $k$-th time with a value of 1 when emergency vehicle can access to link $i$ from origins of $p \%$ and 0 when not

The set of road link in Region $A$

$\begin{array}{ll}R & : \text { The set of road link in } \\ L_{i} & : \text { The length of link } i\end{array}$

$l_{i, k}(p)$ : The passable length of link $i$, which can be accessible from origins of $p \%$, at the $k$-th time

$n_{A} \quad:$ The number of origins in Region $A$, which are accesible from link $i(1 \leq$ $\left.N_{A} \leq N_{A}\right)$

$N_{A} \quad$ : The total number of origins in Region $A$

(b) Definition of LI ratio and NI ratio

Fig. 1 Definition of accessibility indicies

\section{3. アクセシビリティ評価のための緊急車両シミュレーションモデ ルの概要}

緊急輸送道路を用いた緊急車両の空間移動を記述するシミュレー ションモデルの概要を, Fig. 2 に示してある。本モデルは, 道路閉 塞モデルと緊急車両移動モデルから構成される。なお, 本稿で用い る緊急車両シミュレーションモデルは, 前稿 ${ }^{5}$ で構築したモデルに おいて, 道路閉塞モデルの精緻化, および, 緊急活動モデルの高速 化（計算負荷の軽減）を行い，改良したモデルである。

(1) 道路閉塞モデル

道路閉塞モデルでは, 沿道建築物の全壊状況に基づき, 道路リン クごとの閉塞状況を推定する。まず, 兵庫県南部地震 (1995 年) の 実被害データに基づく構造別（木造・ $\mathrm{RC}$ 造・ $\mathrm{S}$ 造・軽量 $\mathrm{S}$ 造）お よび建築年別（木造 5 区分，その他の構造は 3 区分）の建物被害関 数 ${ }^{12)}$ を用いて, 建物 $i$ に被災ランク $\mathrm{R}$ 以上の被害が発生する確率 $P_{\mathrm{R}}(i)$ を推定する (Fig. 3(a))。本モデルでは, 神戸市が実施した調查 の判定基準に基づいて定義された被災ランク（全壊）を用いており ${ }^{13)}$, 回帰係数 $(\lambda, \xi)$ の值は, 東京都の報告 ${ }^{14)}$ を参考に設定した。 その上で, 建物ごとに推定した全壊確率 $P_{\mathrm{R}}(i)$ を用いて, 一様乱数 によって全壊有無を判定する（Fig. 4(b)）。なお，前稿 ${ }^{5)}$ では， Is 值 に基づく建物倒壊確率モデル ${ }^{15)}$ を用いて, 建物ごとに倒壊確率を 推定したが, 本稿では, 使用可能な GIS データの属性情報を考慮 し, 実構造・建築年に基づく建物全壊確率モデル ${ }^{12}$ を用いる。次 に, 各道路リンクの閉塞状況を判定する。前稿 ${ }^{5}$ では, 建築物が倒 壞して, 前面道路を閉塞させるという現象をモデル化し, 各道路リ ンクの閉塞状況を判定した。本稿では, 沿道建築物の前面道路側へ

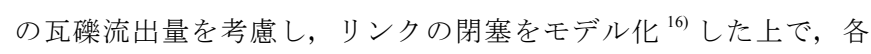




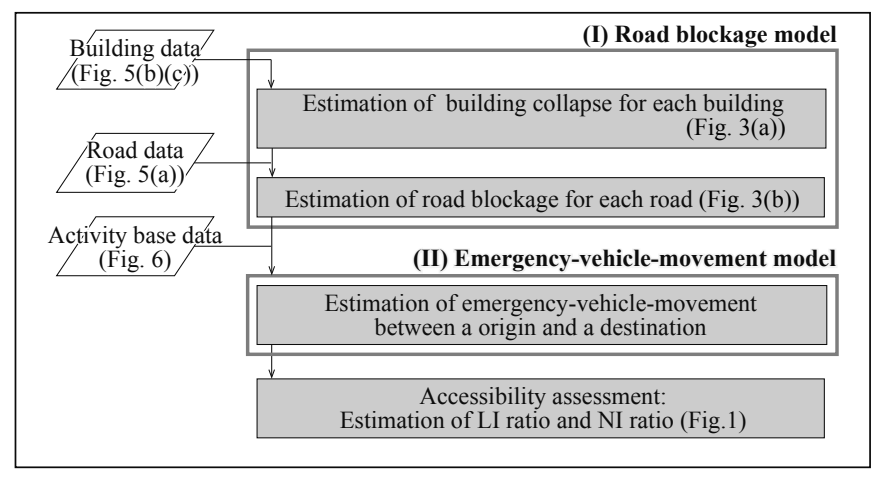

Fig. 2 Overview of simulation model

道路リンクの閉塞状況を判定した。具体的には，全壊した沿道建築 物による瓦磁の飛散状況から, 全壊建物 $i$ の前面道路 $j$ が通行可能 である確率 $f_{i}(j)$ を推定し, 各道路リンクの閉塞確率 $P_{\mathrm{b}}(j)$ を推定す る (Fig. 3(b))。その上で, 各道路リンクの閉塞確率 $P_{\mathrm{b}}(j)$ を用いて, 一様乱数によって閉塞有無を判定する (Fig. 4(d))。本稿では，有効 幅員が $4.0 \mathrm{~m}$ 未満となった場合に, 緊急車両の通行が不能である（閉

塞）と想定する。

\section{（2）緊急車両移動モデル}

緊急車両移動モデルでは，道路閉塞状況を考慮した上で，グラフ 探索アルゴリズムを用いて, 出発地点（各道路リンク）から目的地 点 (活動拠点) への到達可否を推定する。前稿 ${ }^{5}$ で構築した緊急車 両移動モデルでは, Dijkstra 法 ${ }^{17)}$ を用いて, 出発地点から目的地点 への到達可否および移動経路を推定した。しかし，本稿では，出発 地点から目的地点までの所要移動時間などの情報は扱わず，到達可 否に関する情報のみを取得するため, Dijkstra 法に変わって, 幅優 先探索 ${ }^{18)}$ を用いる。これによって, 各活動拠点へ到達可能な道路 リンクの抽出に要する計算負荷を, 大幅に軽減することが可能とな る。この時, 活動拠点への到達可能な経路が存在しない道路リンク については，到達不能であると判定する。

\section{4. 緊急車両シミュレーションにおける使用データと設定条件 (1) 使用データ}

分析対象とする沿道建築物, 緊急輸送道路, および, 活動拠点（災 害拠点病院）のデータに関する概要を Fig. 5，Fig. 6 に示してある。

建築物については, 東京都都市計画 GIS データの一部である土 地・建物利用現況調查 ${ }^{19), 20)}$ を用いる（対象建物数 102,087 棟）（Fig. $5(b))$ このデータでは, 各建築物の所在地や建物高さは得られて いるが，実構造や建築年などの詳細な属性情報が得られていない。 そのため, 本稿では, 町丁目単位で得られている実構造別・建築年 別の建物割合クロス集計表を元に，各建築物の詳細な属性を推定寸 る。なお, 本稿では, 薄井らの建物敷地の接道に関する研究 ${ }^{21)}$ 参考に, 道路境界線から $4.0 \mathrm{~m}$ 未満に存在する建築物を沿道建築物 と見なす $($ Fig. 5(b)(c))。

アクセシビリティが脆弱な沿道区域の抽出を行う上では，同等の 通行機能が求められる道路リンク集合を対象にアクセシビリティ評 価を行う必要がある。そこで, 本稿では, 通行機能の確保が特に急 務である緊急輸送道路のみの利用を想定した緊急車両シミュレー ションを実行する。なお，緊急輸送道路以外の道路リンクの利用を 想定したアクセシビリティ評価については，別途，議論を行う ${ }^{22}$ 。

$$
P_{\mathrm{R}}(i)=\Phi[(\ln (P G V(i))-\lambda) / \xi]
$$

$P_{R}(i)$ : The probability of building $i$ collapse

$\mathrm{R}$ : "Collapsed" or "partially destroyed"

$P G V(i)$ : The value of Peak Ground Velocity of building $i[\mathrm{~cm} / \mathrm{s}]$

$\Phi$ : Cumulative distribution function

$\lambda, \xi$ : The average and the standard deviation of $\ln (\mathrm{PGV})$; they vary according to the structure material and the construction year of a building.

(a) Estimation formula of building collapse ratio ${ }^{12}$ )

$$
\begin{gathered}
f_{i}(j)=D c(i)(1.1753 \cdot S c(i)-0.0514) \\
\cdot \exp \left(\frac{-W_{\mathrm{e}}(j)}{2.58 C r(i)^{0.379}+0.210 F l(i)^{2.23}+4.90 S c(i)^{12}}\right) \\
P_{\mathrm{b}}(j)=1-\prod_{i \in G(j)}\left(1-f_{i}\left(W_{\mathrm{e}}(j)\right)\right)
\end{gathered}
$$

$P_{\mathrm{b}}(j)$ : The probability that road $j$ is blocked

$f i(j)$ : The probability that the debris of collapsed building i outflow to the $\operatorname{road} j$

$D c(i)$ : The collapsed condition of building $i$, with a value of 1 when completely collapsed and 0 when not

$S c(i)$ : The bulding coverage ratio of building $i$

$W e(j)$ : The effective width of a road $j$

$\mathrm{Cr}(i)$ : The average ratio of completely collapsed buildings in the block in which the building $i$ is located

$F l(i)$ : The number of stories of building $i$

$G(j)$ : The set of roadside buildings of road $j$ that generate the debris

(b) Estimation formula of road blockage ratio ${ }^{16}$

Fig. 3 Road blockage model

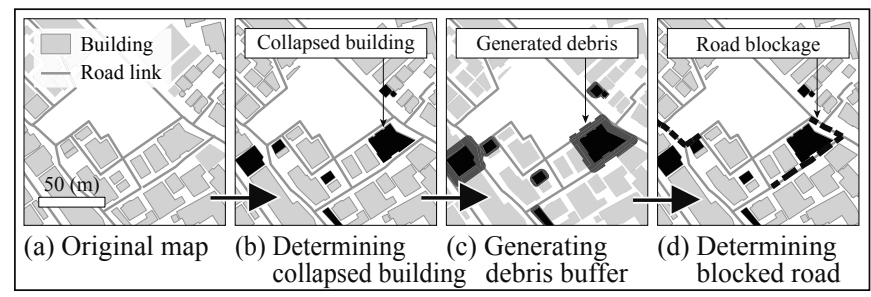

Fig. 4 Estimation of road blockage

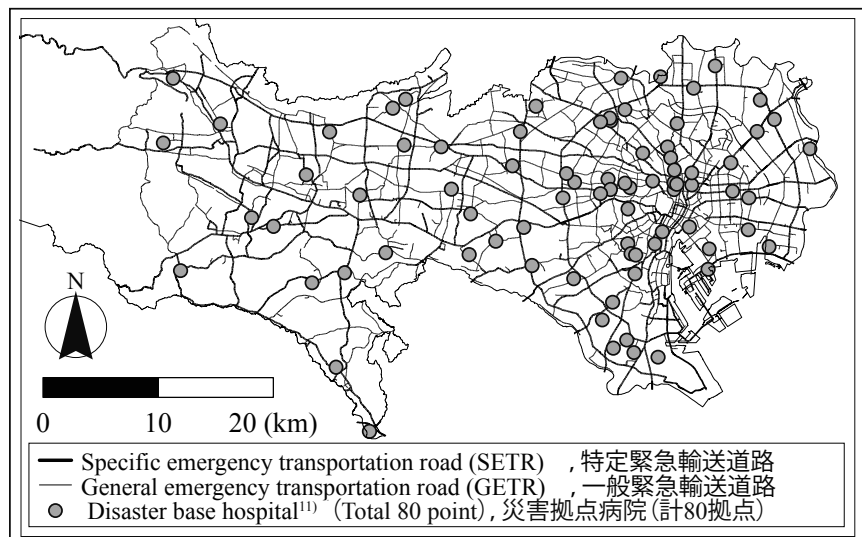

(a) Spatial distributions of emergency transportation road (ETR) and disaster base hospital

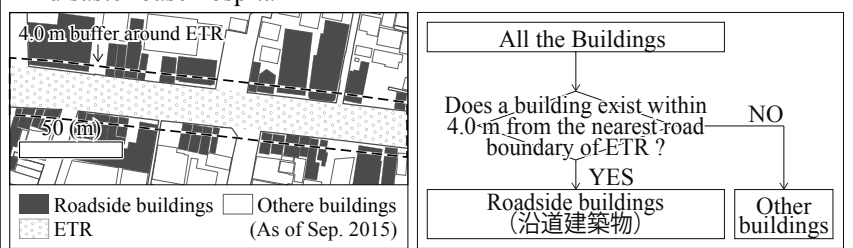

(b) Roadside building data

(c) Classification of buildings along ETR

Fig. 5 Overview of building and road data 
緊急輸送道路については，道路長さや道路幅員などの情報が含まれ ている GIS データ (対象リンク数 26,954 本, 対象ノード数 26,158 個) に，国土交通省が公開している道路ネットワークデータ ${ }^{23)}$ を参考 に，緊急輸送道路に関する属性を付与した（Fig. 5(a)）。

活動拠点の例として用いる災害拠点病院（計 80 箇所）は, 災害 時における東京都の医療救護活動（傷病者の受け入れおよび医療救 護班の派遣など）の拠点となる病院である ${ }^{11)}$ (Fig. 6)。一般に，災 害時における医療体制は，二次医療圈（病院等における入院に係る 医療を提供可能な地域単位) 単位で整備され, 各災害拠点病院は, 当該圈内において医療救護活動を行う。災害拠点病院については, 東京都が公表している災害拠点病院一覧 ${ }^{24)}$ を元に GIS データを作 成し, その立地状況を仔細に確認した上で, 周辺の緊急輸送道路と の接続関係を設定した。

\section{(2) シミュレーションの設定条件}

一般に, 地震の被害想定では, 首都直下地震や東京湾北部地震な どの具体的な地震を想定し, 被害を推定することが多い。しかし, このような想定下では, 物的被害やアクセシビリティ脆弱区域の発 生分布が, 震源位置に近い地域において, より深刻となり, 震源の 想定に大きく依存した評価となる。一方，具体的な地震を想定せ ず，全ての地域で一律の摇れを想定する場合，各地域における道路 リンクと沿道建築物との関係を, 震源位置に関係なく評価すること が可能となる。本稿では, 震源位置や地盤性状の影響を考慮せず, 各災害拠点病院へのアクセシビリティを相対的に評価することを目 的とするため, 全ての地域で一律の摇れを想定する注2)。具体的に は, 東京湾北部地震および都心南部直下地震の被害想定結果におい て, 震源位置付近の地域では, 震度 6 強の強い震度が予想されるこ とを参考に, すべての地点において計測震度 6.2 (震度 6 強の中間值) の摇れを想定した。さらに, 童ら ${ }^{25)}$ の手法を用いて地表面最大速 度 $(\mathrm{PGV})$ に換算した值 $(66 \mathrm{~cm} / \mathrm{s})$ を, シミュレーションにおける 地震強度とした。

緊急車両シミュレーションモデルを用いて, 建築物単位で全壊判 定を行い, 緊急輸送道路の閉塞状況を推定した。緊急車両は, 緊急 輸送道路を用いて, 各災害拠点病院へ移動すると想定した。災害時 における医療救護活動は, 該当する二次医療圈内の災害拠点病院が 担うと仮定し, アクセシビリティ指標を算出した。以降の分析で は, LI 值は「全シミュレーション試行 $(K$ 回）の内, 道路リンク $i$ から到達可能である二次医療圈 $A$ 内の災害拠点病院の割合が $p_{A}$ 未 満であった回数の割合」を, NI 值は「二次医療圈 $A$ における孤立 リンクの総延長 $\left(l_{A}\left(p_{A}\right)\right)$ が, 二次医療圈 $A$ 内の道路網の総延長 $\left(L_{A}\right)$ に占める割合 $\left(l_{A}\left(p_{A}\right) / L_{A}\right) 」 を$ 示している。以上の準備の下で, 緊 急車両シミュレーションを $K=100$ 回実行した。

\section{5. 東京都内の緊急輸送道路を用いた災害拠点病院へのアクセシビ リティ評価}

\section{(1) 道路閉塞率の空間分布}

緊急輸送道路における道路閉塞率の空間分布を Fig. 8(a)(b) に示し てある。23 区北部（Fig. 8(b)）や23 区西部（Fig. 8(b)Area I）におい て, 道路閉塞率の高い道路リンクが存在するものの, 道路閉塞率 が $10.0 \%$ を超える道路リンクは, 全体の $5.9 \%$ に留まる（Fig. 7(a)）。 緊急輸送道路は, 広幅員道路を中心に指定されているため, 道路閉

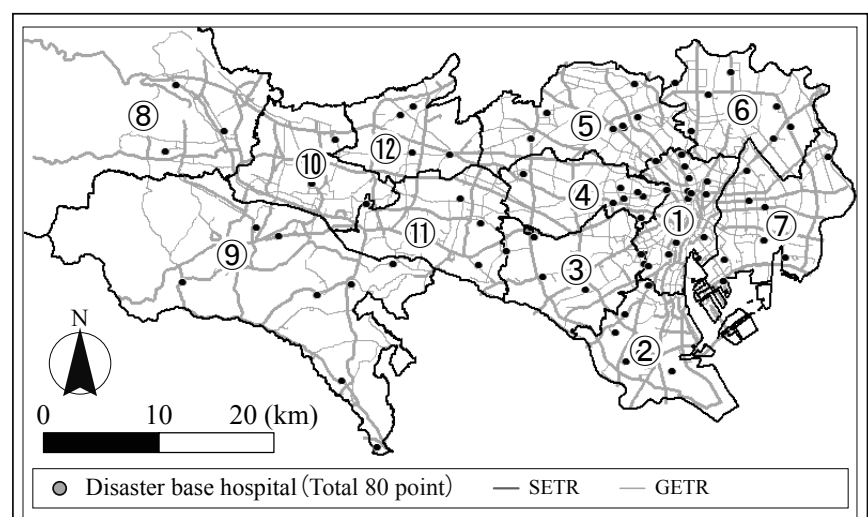

(a) Spatial distributions of secondary healthcare service area and disaster base hospital

\begin{tabular}{llll}
\hline No. Name & \multicolumn{4}{c}{ No. Name } \\
\hline (1) $K u$ Chuobu & (区中央部) & (7) Ku Tobu & (区東部) \\
(2) $K u$ Nanbu & (区南部) & (8) Nishi-Tama & (西多摩) \\
(3) $K u$ Seinanbu & (区西南部) & (9) Minami-Tama & (南多摩) \\
(4) $K u$ Seibu & (区西部) & (10) Kita-tama Seibu & (北多糜西部) \\
(5) $K u$ Seihokubu & (区西北部) & (11) Kita-tama Nanbu & (北多摩南部) \\
(6) $K u$ Tohokubu & (区東北部) & (12) Kita-tama Hokubu & (北多摩北部) \\
\hline (b) List of secondary healthcare service area, 二次医療圏一覧
\end{tabular}

Fig. 6 Overview of disaster base hospital and secondary healthcare service area

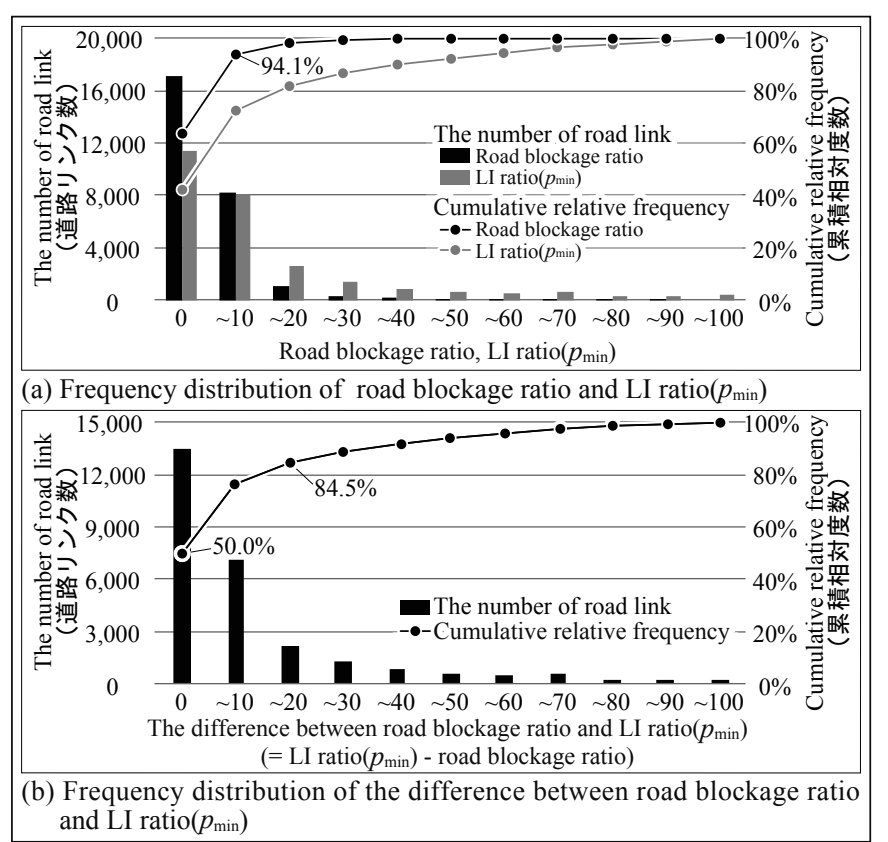

Fig. 7 Spatial distributions of road blockage ratio and LI ratio

塞率は低い傾向にある。

\section{(2) LI 值の空間分布}

道路リンクが, いずれの災害拠点病院へも到達不能な場合の LI 值 $\left(p_{\min }\right)$ について検討する。なお，本稿では，二次医療圈内の全災 害拠点病院 $(N$ 箇所) に占める到達可能な災害拠点病院（ $n$ 箇所） の割合 $p(=n / N)$ の最小值 $(n=1)$ を, $p_{\min }(=1 / N)$ と定義する。LI 值 $\left(p_{\text {min }}\right)$ と道路閉塞率の差についての度数分布, および, 累積相対 度数分布を Fig. 7(b) に示してある。LI 值 $\left(p_{\min }\right)$ は, 全体の $50.0 \%$ の 道路リンクで道路閉塞率よりも高い值を示し, 全体の $15.5 \%$ の道路 リンクで, 20.0 ポイント以上の差が生じている。各道路リンクが孤 立するか否か值は, 自身の閉塞状況だけでなく, 周辺の道路リンク の閉塞状況からも影響を受けるため, LI 值 $\left(p_{\text {min }}\right)$ は, 道路閉塞率よ 


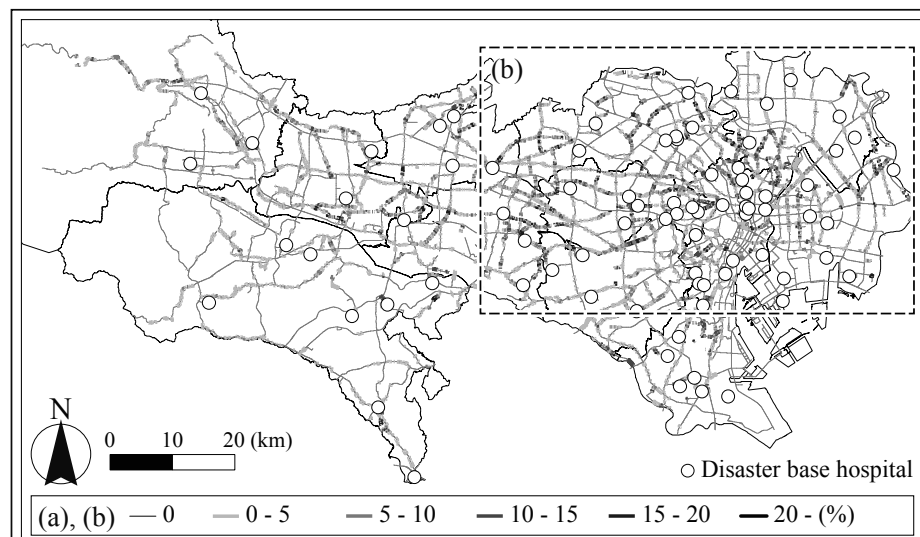

(a) Spatial distribution of road blockage ratio

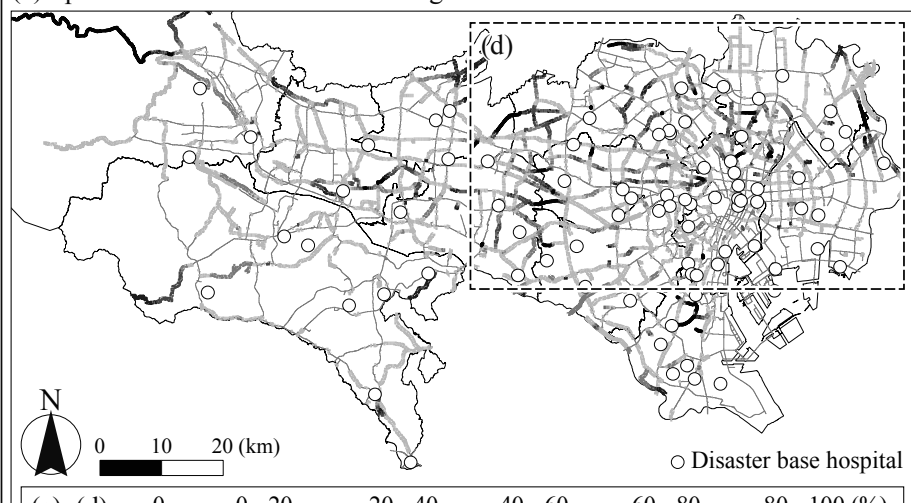

(c), (d) -0 $-0-20 \quad-20-40 \quad-40-60 \quad-60-80 \quad-80-100(\%)$

(c) Spatial distribution of LI $\operatorname{ratio}\left(p_{\min }\right)$

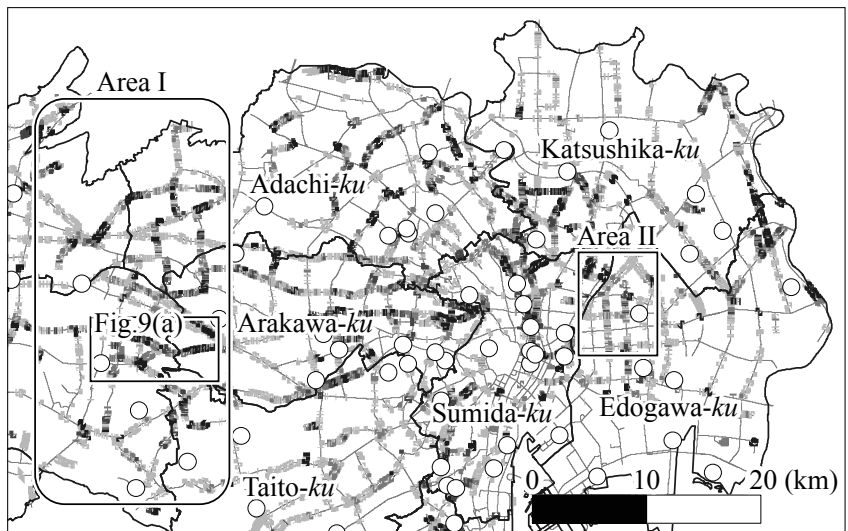

(b) Spatial distribution of road blockage ratio (Enlarged view)

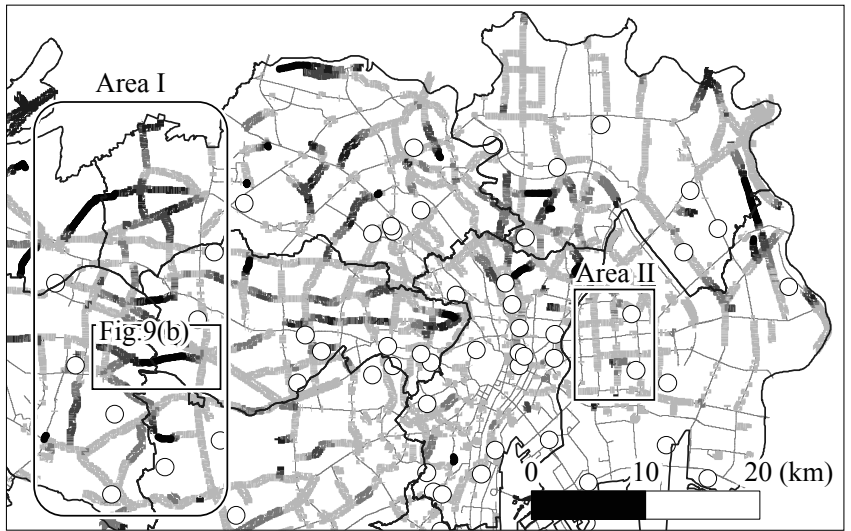

(d) Spatial distribution of LI ratio $\left(p_{\min }\right)$ (Enlarged view)

Fig. 8 Spatial distributions of road blockage ratio and LI ratio

りも高い值を示すことがわかる。次に, 緊急輸送道路の LI 值 $\left(p_{\min }\right)$ の空間分布を Fig. 8(c)(d) に示してある。なお，道路閉塞率と LI 值 の空間分布は，凡例の目盛間隔が異なる（Fig. 8(a) (d))。LI 值 $\left(p_{\min }\right)$ の空間分布をみると, 道路閉塞率の空間分布のみからは読み 取ることが困難であった, 災害拠点病院へのアクセシビリティが脆 弱な沿道区域を把握することができる。例えば，緊急輸送道路が密 に整備されているエリアでは（Fig. 8(d) Area II), 緊急車両が道路閉 塞に遭遇した場合も，複数の迂回経路が存在するため, LI 值 $\left(p_{\min }\right)$ が広域に悪化することはない。一方, 緊急輸送道路の整備が疎であ るエリアでは, 道路閉塞に遭遇した際に, 迁回経路が存在しないた め，広い範囲で孤立リンクが発生する傾向が見てとれる（Fig. 9(a) (b))。

\section{(3) 災害拠点病院ごとの NI 值}

各災害拠点病院へのアクセシビリティに着目して求めた NI 值を Fig. 10 に示してある。69箇所（全体の $86.3 \%$ ）の災害拠点病院に おいて, NI 值は 20.0\% 以下の低い值を示すが, 7 箇所（全体の 8.8\%） の災害拠点病院では， $50.0 \%$ を上回る值を示す (Fig. 10(a)(b))。NI 值が特に高い值を示寸災害拠点病院では, 複数の移動経路が選択可 能である（3 本以上の道路リンクが接続する）交差点までの距離が 長い。そのため, 災害拠点病院周辺で道路閉塞が発生した場合, 迂 回経路が存在せず, 災害拠点病院へ到達が不能となる可能性が高い (Fig. 9(c)(d))。これらの災害拠点病院のアクセシビリティを改善す るためには, 災害拠点病院周辺において沿道建築物の耐震化を重点 的に促進することが重要であると考えられる。

(4) 二次医療圏ごとの NI 值

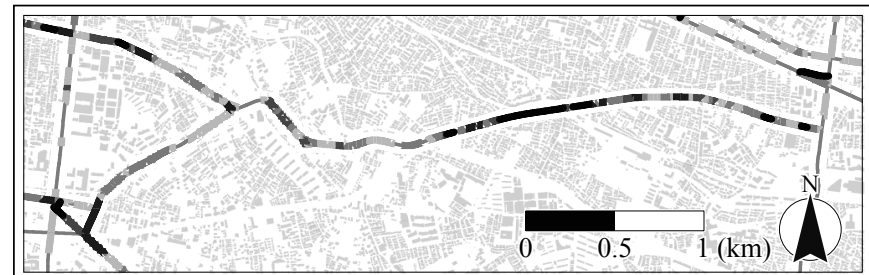

(a) Spatial distribution of road blockage ratio along Hitomi-Kaido

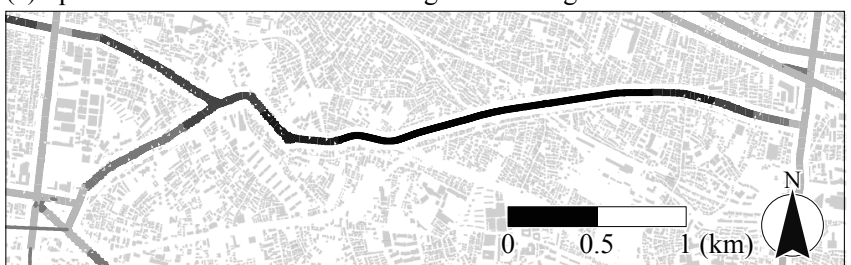

(b) Spatial distribution of LI ratio $\left(p_{\min }\right)$ along Hitomi-Kaido

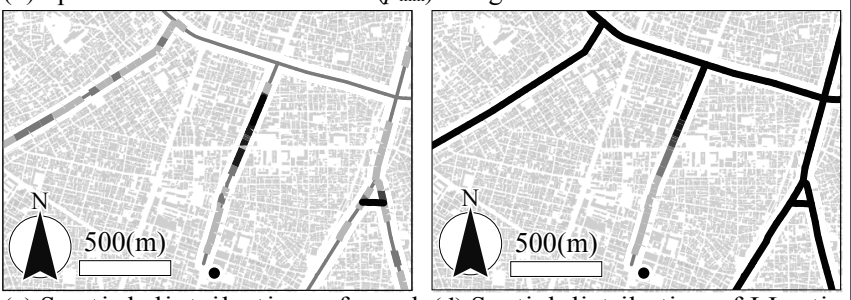

(c) Spatial distribution of road (d) Spatial distribution of LI ratio blockage ratio around Toho around Toho University Omori University Omori Medical Center Medical Center

$\square$ Building $\bullet$ Toho University Omori Medical Center (a), (c) Road blockage rate
$-0-0-5-10-10-15-15-20-20-(\%)$
(b), (d) LI ratio $\left(p_{\min }\right)$ (b), (d) LI ratio $\left(p_{\min }\right)$
$-0 \quad-0-20 \quad-20-40 \quad-40-60 \quad-60-80 \quad-80-100(\%)$

Fig. 9 Spatial distributions of road blockage ratio and LI ratio in partial areas 


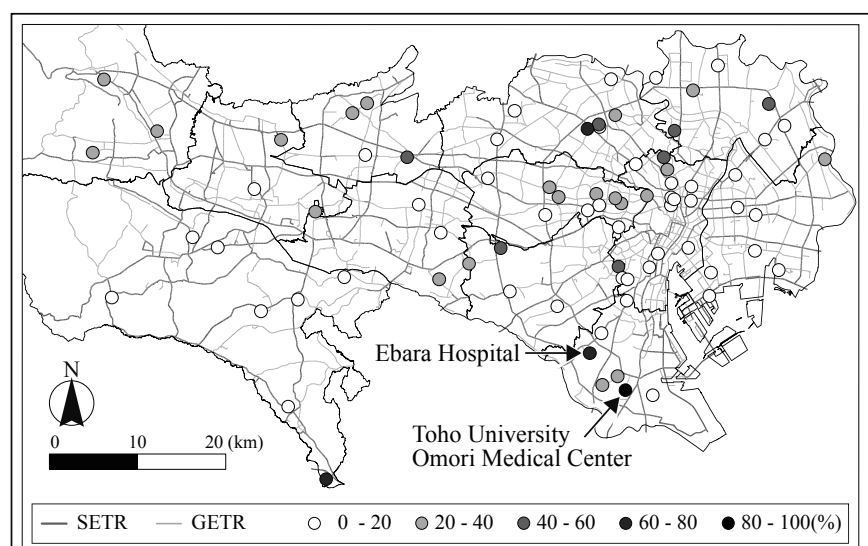

(a) Spatial distribution of NI ratio of each disaster base hospitals

\begin{tabular}{clc}
\hline No. & \multicolumn{1}{c}{ Hospital name } & NI ratio \\
\hline 1 & Toho University Omori Medical Center & $93.9 \%$ \\
2 & Ebara Hospital & $78.7 \%$ \\
3 & Nihon University Itabashi Hospital & $70.1 \%$ \\
4 & Minami Machida Hospital & $61.9 \%$ \\
5 & Tokyo Women's Medical University Medical Center East & $58.7 \%$ \\
6 & Tokyo Metropolitan Komagome Hospital & $57.6 \%$ \\
7 & Sassa General Hospital & $54.1 \%$ \\
8 & Tokyo Metropolitan Matsuzawa Hospital & $49.9 \%$ \\
9 & Toshima Hospital & $46.5 \%$ \\
10 & Tobu Chiiki Hospital & $44.7 \%$ \\
\hline (b) List of disaster base hospital (The bottom 10 hospitals of NI ratio)
\end{tabular}

Fig. $10 \mathrm{NI}$ ratio of disaster base hospital

二次医療圈ごとに $p$ の值を変化させながら求めた NI 值を, Fig. 11 に示してある。西多摩や北多摩北部などの二次医療圈では, NI 值 $\left(p_{\mathrm{min}}\right)$ が高い值を示す (Fig. 11 (8)(12))。これらの二次医療圈では, いずれの災害拠点病院へも到達不能な沿道区域が発生し，傷病者が 医療救護活動を受けられない可能性がある。また，NI 值が高い災 害拠点病院（東邦大学医療センター大森病院や日本大学医学部附属 板橋病院など）が存在する二次医療圈（区南部や区西北部など）で は，一部の災害拠点病院へのアクセスが困難となる（Fig. 11 (2)(5)）。 このような二次医療圈では, 圈域内の医療救護機能が, 少数の災害 拠点病院に偏る可能性が高い。災害拠点病院周辺および LI 值が高 い道路リンクの沿道建築物を優先的に耐震化するなど, 二次医療圈 ごとに NI 值を改善するための施策について検討する必要がある。

\section{6. まとめ}

本稿では，活動拠点へのアクセシビリティが大地震時に脆弱とな る沿道区域の抽出方法を提案した。具体的には，まず，大地震時の 物的被害下における孤立リンクに着目したアクセシビリティ指標 (リンク孤立率（LI 值），および，ネットワーク孤立率（NI 值））を 提案した。次に, 前稿 ${ }^{5}$ で構築した大地震時の道路閉塞状況を道路 リンク単位で記述するための道路閉塞モデルと緊急車両の空間移動 を記述する緊急車両移動モデルを組み合わせた緊急車両シミュレー ションモデルを改良した。その上で, 東京都全域において, 地表面 最大速度 $(P G V) 66 \mathrm{~cm} / \mathrm{s}$ の摇れを想定したシミュレーションを実 行し, 緊急輸送道路を用いた災害拠点病院（計 80 箇所）へのアク セシビリティ評価を行った。

LI 值を用いて, 災害拠点病院へのアクセシビリティが脆弱な沿 道区域を示した。特に, 緊急輸送道路の整備が疎であるエリアでは,

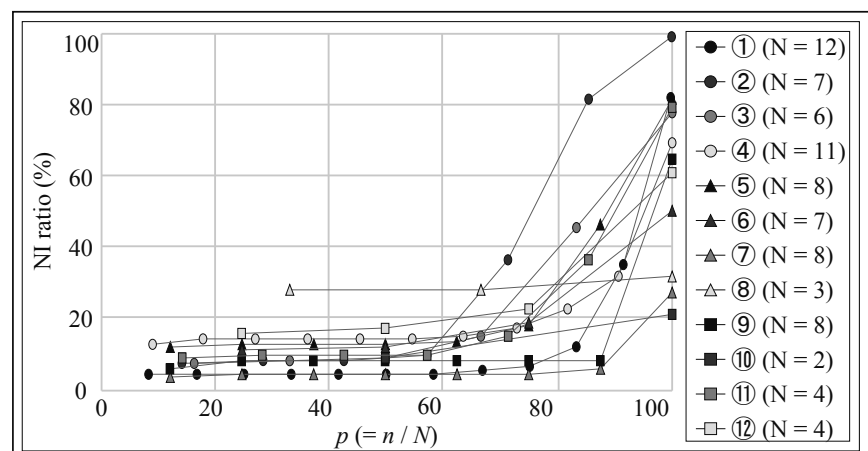

(a) Relationship between NI ratio and $p$, the ratio of accessible disaster base hospitals in secondary healthcare service area

\begin{tabular}{|c|c|c|c|c|c|c|c|}
\hline No. & Name & $p_{\min }$ & $p=1$ & No. & Name & $p_{\text {min }}$ & $p=1$ \\
\hline (1) & Ku Chuobu & $4.1 \%$ & $81.7 \%$ & (7) & Ku Tobu & $3.8 \%$ & $26.9 \%$ \\
\hline (2) & Ku Nanbu & $7.2 \%$ & $99.1 \%$ & (8) & Nishi-Tama & $28.1 \%$ & $31.7 \%$ \\
\hline (3) & Ku Seinanbu & $7.5 \%$ & $77.9 \%$ & (9) & Minami-Tama & $6.0 \%$ & $65.1 \%$ \\
\hline (4) & Ku Seibu & $13.2 \%$ & $69.5 \%$ & (10) & Kita-tama Seibu & $9.0 \%$ & $20.8 \%$ \\
\hline (5) & Ku Seihokubu & $12.4 \%$ & $81.4 \%$ & (11) & Kita-tama Nanbu & $11.3 \%$ & $50.2 \%$ \\
\hline (6) & Ku Tohokubu & $9.1 \%$ & $79.1 \%$ & (12) & Kita-tama Hokubu & $16.1 \%$ & $61.2 \%$ \\
\hline
\end{tabular}

Fig. 11 Transition of NI ratio in secondary healthcare service area

広い範囲で孤立リンクが発生する傾向があることを示した。また， 災害拠点病院ごとの NI 值をみると,7箇所の災害拠点病院において, $50.0 \%$ を超える非常に高い值を示した。このような災害拠点病院が 存在する二次医療圈では, 医療救護の負荷が少数の災害拠点病院に 集中する可能性が高い。災害拠点病院周辺，および，LI 值が高い 值を示す道路リンクの沿道建築物を優先的に耐震化するなど，アク セシビリティの改善施策について検討する必要がある。

本研究では, 道路の沿道建築物が拠点施設へのアクセシビリティ に与える影響を把握するため, 建物全壊に起因する道路閉塞のみに 着目して議論を行った。しかし, 大地震時における, 医療救護活動 を想定したアクセシビリティ評価は, 重症者の発生分布や災害拠点 病院の病床数（受け入れ可能人数）に大きく依存する。円滑な医療 救護活動を実現するためにも, これらの要因を考慮し, 災害拠点病 院ごとの受け入れ重傷者数, および, 収容キャパシティの超過によ り受け入れ不能となる重傷者数などについての, より具体的な分析 が必要である。これらについては, 今後の課題としたい。

本稿は, 地理情報システム学会論文集 ${ }^{26)}$ における発表内容をも とに, 新たな分析を加え, 全面的に書き改めたものである。

注

注 1) 各地方自治体は, 大地震発生時に救急救命活動の生命線となる幹線道路 を, 緊急輸送道路に指定している。さらに, 東京都では, 緊急輸送道路（約 $2,000 \mathrm{~km})$ のうち特に沿道建築物の耐震化を図る必要があると認められる道 路を特定緊急輸送道路（約 $1,000 \mathrm{~km}$ ) に指定し（これ以外は一般緊急輸送道 路), 道路を閉塞させる危険性の高い建築物（特定沿道建築物）の所有者・ 管理者に対して, 而震診断または而震改修の実施状況などについての報告を 義務付けている ${ }^{1), 2,3)}$ 。

注 2) 大地震時のアクセシビリティの評価方法としては, 具体的な震源地（特 定の想定地震）を設定して，その地震の影響を評価する方法（方法 1)，震 源地をランダムに多数想定し，これらの影響を平均值で評価する方法 (方法 2), 全ての地点において一律の摇れを想定して評価する方法（方法 3）が考 えられる。方法 1 は, 具体的な想定地震がアクセシビリティに及ぼす影響を 直接的に評価することができる。しかし，震源地から遠い地域には影響が 及ばないため, 局所的な評価となり，東京都全域について評価したい場合に は不向きといえる。方法 2 では，東京都全域を偏りなく評価することは可 能であるが, 地震の影響の程度が平滑化され, 被害の様相が過小評価され る危険性がある。方法 3 では, 東京都全域が震源地に近い場所と同程度に 
強く摇れるという過大な想定であるため, 地震強度の地域差は反映されず, 被害の様相は過大評価となる可能性がある。しかし，本稿では，東京都全域 を移動するような広域移動ではなく，二次医療圈内での空間移動について検 討することから, 地震強度の地域差は大きく影響しないと判断して, 方法 3 を採用することとした。

\section{参考文献}

1) Tokyo Metropolitan Government.: Promoting the Seismic Resistance of Buildings, http://www.taishin.metro.tokyo.jp/pdf/tokyo/sokushinkeikaku_2.pdf, 2016. 3 (accessed 2019.9.29), (in Japanese)

東京都：東京都耐震改修促進計画, http://www.taishin.metro.tokyo.jp/pdf/tokyo/ sokushinkeikaku_2.pdf, 2016.3 (2019.9.29 参照)

2) Tokyo Metropolitan Government.: Regulation to Promote Seismic Retrofit of Buildings along the Emergency Transportation Roads, http://www.reiki.metro.tokyo. jp/reiki honbun/ag10141981.html, 2011. 3 (accessed 2019.9.29), (in Japanese) 東京都：東京における緊急輸送道路沿道建築物の耐震化を推進する条例， http://www.reiki.metro.tokyo.jp/reiki_honbun/ag10141981.html, 2011. 3 (2019.9.29 参照)

3) Tokyo Metropolitan Government.: Further Strategy on Promotion of the Seismic Resistance of Buildings along the Specific Emergency Transportation Roads, http:// www.taishin.metro.tokyo.jp/pdf/tokyo/consideration_houkoku.pdf, 2018.5(accessed 2020.3.4), (in Japanese)

東京都: 特定緊急輸送道路沿道建築物の耐震化に向けた更なる促進策につい て, http://www.taishin.metro.tokyo.jp/pdf/tokyo/consideration_houkoku.pdf, 2018.5, (2020.3.4 参照)

4) Tokyo Metropolitan Government.: Seismic Status of Buildings along the Specific Emergency Transportation Roads, http://www.taishin.metro.tokyo.jp/tokyo topic04_0112.html, 2020.12(accessed 2020.3.4), (in Japanese)

東京都：特定緊急輸送道路沿道建築物の耐震化の状況について, http://www taishin.metro.tokyo.jp/tokyo/topic04 0112.html, 2020.12, (2020.3.4 参照)

5) Osaragi, T. and Kishimoto, M.: Accessibility Evaluation of Specific Emergency Transportation Roads and Effects of Quake-Resistant-Conversion of Roadside Buildings, Journal of Architecture and Planning (Transactions of AIJ), Vol. 84, No. 764, pp. 2175-2182, 2019. 10 (in Japanese)

大佛俊泰, 岸本まき: 特定緊急輸送道路のアクセシビリティ評価と沿道建築 物耐震化の効果, 日本建築学会計画系論文集, Vol. 84, No. 764, pp. 2175-2182, 2019. 10

6) Seto, Y., Uno, N. and Shiomi, Y.: A Physician Allocation Model Based on Accessibility Index Considering Non-overlapping Path, Journal of Japan Society of Civil Engineers, Ser. D3 (Infrastructure Planning and Management), Vol. 67, No. 5, pp. I_57-I_68, 2011 (in Japanese)

瀬戸裕美子, 宇野伸宏, 塩見康博: 非重複経路数を考慮したアクセシビリティ 指標に基づく医療施設配置計画, 土木学会論文集 D3(土木計画学), Vol. 67, No. 5, pp. I_57-I_68, 2011.

7) Harada, T., Kurauchi, F. and Takagi, A.: Connectivity Vulnerability Evaluation Based on Potential Accessinility Considering a Redundancy of Road Network, Journal of Japan Society of Civil Engineers, Ser. D3 (Infrastructure Planning and Management), Vol. 70, No. 1, pp. I_76-87, 2014 (in Japanese)

原田剛志, 倉内文孝, 高木朗義 :リダンダンシーを考慮したアクセシビリティ 指標に基づく道路ネットワークの脆弱性評価, 土木学会論文集 D3( 土木計画 学), Vol. 70, No. 1, pp. I_76-87, 2014.

8) Grötschel, M.: Design of survivable networks, Handbooks in Operations Research and Management Science, Vol.7, pp.617-672, 1995.

9) Osawa, S., Fujiu, M., Nakayama, S. and Takayama, J.: Development and Application of an Evaluation Method of the Vulnerable Section to the Earthquake of the Road Network, Journal of Japan Society of Civil Engineers, Ser. A1 (Structural Engineering \& Earthquake Engineering), Vol. 73, No. 4, pp. 467-478, 2017 (in Japanese)

大澤脩司, 藤生慎, 中山晶一朗, 高山純一 : 地震に対する道路網の脆弱区間評 価手法の構築と緊急輸送道路網一の適用, 土木学会論文集 $\mathrm{A} 1$ ( 構造・地震工 学), Vol. 73, No. 4, pp. 467-478, 2017.

10) Harada, S., Eitoku, Y., Tone, T., Miki, S. and Wakabayashi, T. :Practical Evaluation about the Connection Reliability of Road, Journal of Japan Society of Civil Engineers, Ser. D3 (Infrastructure Planning and Management), Vol. 69, No. 5, pp. I_67-I_78, 2013 (in Japanese)

原田慎也, 栄徳洋平, 戸根智弘, 三木智, 若林拓史 : 道路の連結信頼性の実 用的な評価方法の提案, 土木学会論文集 D3(土木計画学), Vol. 69, No. 5, pp.
I_67-I_78, 2013.

11) Breau of Social Welfare and Public Health :The Outline of Installation and Operation of Tokyo Disaster Base Hospital, http://www.fukushihoken.metro.tokyo. jp/iryo/kyuukyuu/saigai/kyotenbyouinlist.files/kyotenyoko.pdf (accessed 2020.3.4), (in Japanese)

東京都福祉保健局：東京都災害拠点病院設置運営要綱, https://www. fukushihoken.metro.tokyo.lg.jp/iryo/kyuukyuu/saigai/kyotenbyouinlist.files/ kyotenyoko.pdf (2020.3.4 参照)

12) Murao, O. and Yamazaki, F.:Development of Fragility Curves for Buildings Based on Damage Survey Data of a Local Government after the 1995 Hyogoken-Nanbu Earthquake, Journal of Structural and Construction Engineering (Transactions of AIJ), No. 527, pp.189-196, 2000. 1 (in Japanese)

村尾修，山崎文雄 : 自治体の被害調査結果に基づく兵庫県南部地震の建物被 害関数, 日本建築学会構造系論文集, No. 527, pp. 189-196, 2000.1

13) Murao, O. and Yamazaki, F.:Comparison of Building Damage Evaluation by Local Governments after the 1995 Hyogoken-Nanbu Earthquake, Journal of Structural and Construction Engineering (Transactions of AIJ), No. 515, pp.187-194, 1999. 1 (in Japanese)

村尾修, 山崎文雄 : 兵庫県南部地震における建物被害の自治体による調査法 の比較検討, 日本建築学会構造系論文集, No. 515, pp. 187-194, 1999.1

14) Tokyo Metropolitan Government.: Community Earthquake Risk Assessment Study (8th Edition), https://www.toshiseibi.metro.tokyo.lg.jp/bosai/chousa_6/home.htm, 2018.2(accessed 2020.3.4), (in Japanese)

東京都：地震に関する地域危険度測定調查報告書 (第 8 回), https://www toshiseibi.metro.tokyo.lg.jp/bosai/chousa_6/home.htm, 2018.2 (2020.3.4 参照)

15) Hayashi, Y., Suzuki, Y., Miyakoshi, J. and Watanabe, M.: Seismic Risk Evaluation of Existing RC Buildings Based on Seimic Performance Indices, Journal of Social Safety Science, No. 2, pp. 235-242, 2000.11(in Japanese)

林康裕, 鈴木祥之, 宮腰淳一, 渡辺基史 : 而震診断結果を利用した既存 RC 造 建築物の地震リスク表示, 地域安全学会論文集, No. 2, pp. 235-242, 2000.11

16) Ministry of Land, Infrastructure and Transport: Developments of Technology and Evaluation index of Disaster Mitigation for planning Local Areas, http://www. nilim.go.jp/lab/jdg/soupuro/0.pdf, 2003. 3, (accessed 2018.8.22), (in Japanese).

国土交通省：国土交通省総合技術開発プロジェクトまちづくりにおける防 災評価・対策技術の開発（防災まちづくり総プロ）報告書, http://www.nilim. go.jp/lab/jdg/soupuro/0.pdf, 2003. 3 (2018.8.22 参照)

17) Dijkstra, E. W.: A Note on Two Problems in Connexion with Graphs, Numerische Mathematik, Vol. 1, pp. 269-271, 1959.

18) Moore, E. F.: The shortest path through a maze, Proceedings of the International Symposium on the Theory of Switching, Harvard University Press, pp. 285-292, 1959.

19) Tokyo Metropolitan Government. : Land Use in Tokyo Tokyo 23 Wards 2011Edition Overview of Land Use Survey for FY 2011, http://www.toshiseibi.metro.tokyo.jp/ seisaku/tochi_c/pdf/tochi_3/tochi_all.pdf?1407 (accessed 2019.7.18) 東京都: 東京の土地利用 平成 23 年東京都区部 平成 23 年度土地利用現況調 査の概要, http://www.toshiseibi.metro.tokyo.jp/seisaku/tochi_c/pdf/tochi_3/tochi_ all.pdf?1407 (2019.7.18 参照)

20) Tokyo Metropolitan Government. : Land Use in Tokyo Tama and Island Areas 2012 Edition Overview of Land Use Survey for FY 2012, http://www.toshiseibi.metro. tokyo.jp/seisaku/tochi_c/pdf/tochi_4/tochi_all.pdf (accessed 2019.7.18) 東京都: 東京の土地利用平成 24 年多摩・島しょ地域 平成 24 年度土地利用 現況調査の概要, http://www.toshiseibi.metro.tokyo.jp/seisaku/tochi_c/pdf/tochi_4/ tochi_all.pdf (2019.7.18 参照)

21) Usui, H. and Asami, Y.: Study on Methods of Judging Adjacency of Lots to Roads by Using GIS, CSIS Discussion paper, No.95, 2009. 4 (in Japanese)

薄井宏行, 浅見泰司: GIS を用いた建物敷地の接道判定方法に関する研究, CSIS Discussion paper, No.95, 2009. 4

22) Kishimoto, M. and Osaragi, T.: Relationships Between Accessibility of Emergency Vehicles and Local Environments in Tokyo Metropolitan Area After a Large Earthquake, Journal of Disaster Research, Vol. 14, No. 3, pp. 489-499, 2019. 3

23) Ministry of Land, Infrastructure, Transport and Tourism: National Land Numerical Information Emergency Transportation Road, http://nlftp.mlit.go.jp/ksj-e/gml/ datalist/KsjTmplt-N10-v1_1.html (accessed 2019.2.18)

国土交通省：国土数值情報 緊急輸送道路, http://nlftp.mlit.go.jp/ksj/gml/ datalist/KsjTmplt-N10-v1_1.html (2019.2.18 参照)

24) Breau of Social Welfare and Public Health :Tokyo Disaster Base Hospital, http://www.fukushihoken.metro.tokyo.jp/iryo/kyuukyuu/saigai/kyotenbyouinlist 
html(accessed 2019.7.3)

東京都福祉保健局：東京都災害拠点病院, http://www.fukushihoken.metro.tokyo. jp/iryo/kyuukyuu/saigai/kyotenbyouinlist.html (2019.7.3 参照)

25) Tong, H. and Yamazaki, F.: Relationship between Ground Motion Indices and New JMA Seismic Intensity, Seisan Kenkyu, Vol. 48, No. 11, pp. 31-34, 1996. 11(in Japanese)

童華南, 山崎文雄 : 地震動強さ指標と新しい気象庁震度との対応関係, 生産 研究, Vol. 48, No. 11, pp. 31-34, 1996. 11

26) Kishimoto, M. and Osaragi, T.: Method for Extracting Vulnerable Roadside Areas Based on Accessibility to Disaster Base Hospitals after a Large Earthquake, Papers and Proceedings of the Geographic Information Systems Association (CD-ROM), D-4-5, 2019. 10(in Japanese)

岸本まき, 大佛俊泰 : 大地震発生時における災害拠点病院へのアクセシビリ ティから見た脆弱な沿道区域の抽出方法, 地理情報システム学会講演論文集 (CD-ROM), D-4-5, 2019. 10 


\author{
Maki TAGASHIRA ${ }^{* 1}$ and Toshihiro OSARAGI*2 \\ ${ }^{* 1}$ Assist. Prof., School of Environment and Society, Tokyo Institute of Technology, Dr.Eng. \\ ${ }^{*}$ Prof., School of Environment and Society, Tokyo Institute of Technology, Dr.Eng.
}

As it is predicted that there is a $70 \%$ possibility of an earthquake directly hitting Tokyo metropolitan within the next 30 years, it is an urgent issue to ensure the traffic function of emergency transportation roads (hereafter called "ETR"), which is an important infrastructure that supports emergency activities at the time of a large earthquake (e.g., wide-area evacuation, firefighting activities, ambulance services, etc.). In previous paper, we discussed about the transportation function of ETR after a large earthquake by evaluating the accessibility of ETR and the effects of quake-resistant-conversion of roadside buildings. In this paper, we propose the method for extracting vulnerable accessibility roadside areas, which have high possibility to hinder emergency activities after a large earthquake.

First, to extract the vulnerable roadside areas with poor accessibility, we propose novel indices, Link Isolation ratio (hereafter called "LI ratio") and Network Isolation ratio (hereafter called "NI ratio"). Next, we improve a simulation model, which we had previously constructed. This simulation model is consist of the following two sub-models. The one is the road blockage model that describes the collapse of each roadside building based on the construction year and the structure of each building, and describes the road blockage based on the collapse situation of roadside buildings. The other one is the emergency-vehicle-movement model that describes movement of emergency vehicles to activity bases. Then, performing the simulations, we evaluate the accessibility to disaster base hospitals (total 80 bases) using ETR in Tokyo metropolitan. We examine the simulation results with accessibility indices, LI ratio and NI ratio, which are calculated on the assumption that the medical relief activities are conducted at disaster base hospitals in the corresponding secondary healthcare service area.

LI ratio $\left(p_{\text {min }}\right)$, the possibility of an emergency vehicle cannot access to any disaster base hospital, indicates higher value than road blockage ratio at $50.0 \%$ of road links, and there is a difference of 20.0 points or more between these indices at $15.5 \%$ of road links. This is because the isolation status of each road link is result of not only its own blockage status but also surrounding situations. From the spatial distribution of the LI ratio $\left(p_{\min }\right)$, we can grasp vulnerable roadside areas with poor accessibility to disaster base hospitals. For instance, it is difficult to secure a detour route when emergency vehicle encounters road blockages in an area with sparse road network. In such areas, isolated links tend to occur over a wide range.

NI ratios $\left(p_{\min }\right)$ exceeds $50.0 \%$ at 7 disaster base hospitals ( $8.8 \%$ of the total). In the secondary healthcare service areas with those hospitals, there is a high possibility that the medical relief function is biased toward hospitals with high accessibility. Therefore, it is also important to consider the countermeasures to improve the accessibility to hospitals with poor accessibility. Moreover, NI ratios $\left(p_{\min }\right)$ indicate high value in secondary healthcare service areas such as Nishi-tama and Kita-tama Hokubu. At the time of a large earthquake, there is a possibility that some roadside areas become unreachable to any hospital and patients in those areas may not be able to receive medical relief activities. To improve NI ratios $\left(p_{\min }\right)$ of those areas, there is an urgent need to consider the countermeasures such as quake-resistant-conversion of buildings around disaster base hospitals or road links with high LI ratios. 